Article

\title{
Enhanced Production of (R)-3-Hydroxybutyrate Oligomers by Coexpression of Molecular Chaperones in Recombinant Escherichia coli Harboring a Polyhydroxyalkanoate Synthase Derived from Bacillus cereus YB-4
}

\author{
Saki Goto ${ }^{1,2}$, Yuki Miyahara ${ }^{2,3} \mathbb{D}^{D}$, Seiichi Taguchi ${ }^{1}(\mathbb{D})$, Takeharu Tsuge ${ }^{2,3}$ and Ayaka Hiroe 1,2,* $^{1, *}$ \\ 1 Department of Chemistry for Life Sciences and Agriculture, Faculty of Life Sciences, Tokyo University of \\ Agriculture, 1-1-1 Sakuragaoka, Setagaya, Tokyo 156-8502, Japan; sg207296@nodai.ac.jp (S.G.); \\ st206172@nodai.ac.jp (S.T.) \\ 2 MIRAI, Japan Science and Technology Agency (JST), 4-1-8 Honcho, Kawaguchi, Saitama 332-0012, Japan; \\ miyahara.y.aa@m.titech.ac.jp (Y.M.); tsuge.t.aa@m.titech.ac.jp (T.T.) \\ 3 Department of Materials Science and Engineering, School of Materials and Chemical Technology, \\ Tokyo Institute of Technology, 4259 Nagatsuta, Midori-ku, Yokohama 226-8502, Japan \\ * Correspondence: ah206178@nodai.ac.jp
}

check for updates

Citation: Goto, S.; Miyahara, Y.; Taguchi, S.; Tsuge, T.; Hiroe, A. Enhanced Production of

(R)-3-Hydroxybutyrate Oligomers by

Coexpression of Molecular

Chaperones in Recombinant Escherichia coli Harboring a Polyhydroxyalkanoate Synthase Derived from Bacillus cereus YB-4. Microorganisms 2022, 10, 458. https://doi.org/10.3390/ microorganisms 10020458

Academic Editor: Yuji Aso

Received: 27 January 2022

Accepted: 14 February 2022

Published: 16 February 2022

Publisher's Note: MDPI stays neutral with regard to jurisdictional claims in published maps and institutional affiliations.

Copyright: (c) 2022 by the authors. Licensee MDPI, Basel, Switzerland. This article is an open access article distributed under the terms and conditions of the Creative Commons Attribution (CC BY) license (https:// creativecommons.org/licenses/by/ $4.0 /)$.

\begin{abstract}
The biodegradable polyester poly-(R)-3-hydroxybutyrate $[\mathrm{P}(3 \mathrm{HB})]$ is synthesized by a polymerizing enzyme called polyhydroxyalkanoate (PHA) synthase and accumulates in a wide variety of bacterial cells. Recently, we demonstrated the secretory production of a $(R)-3 \mathrm{HB}$ oligomer (3HBO), a low-molecular-weight $\mathrm{P}(3 \mathrm{HB})$, by using recombinant Escherichia coli expressing PHA synthases. The $3 \mathrm{HBO}$ has potential value as an antibacterial substance and as a building block for various polymers. In this study, to construct an efficient $3 \mathrm{HBO}$ production system, the coexpression of molecular chaperones and a PHA synthase derived from Bacillus cereus YB-4 (PhaRC YB4 $_{\text {) was }}$ examined. First, genes encoding enzymes related to $3 \mathrm{HBO}$ biosynthesis ( $p h a \mathrm{RC}_{Y B 4}, p h a A$ and $p h a B$ derived from Ralstonia eutropha H16) and two types of molecular chaperones (groEL, groES, and tig) were introduced into the E. coli strains BW25113 and BW25113 $\triangle a d h E$. As a result, coexpression of the chaperones promoted the enzyme activity of PHA synthase (approximately 2-3-fold) and $3 \mathrm{HBO}$ production (approximately 2-fold). The expression assay of each chaperone and PHA synthase subunit ( $\mathrm{PhaR}_{\mathrm{YB} 4}$ and $\mathrm{PhaC}_{\mathrm{YB} 4}$ ) indicated that the combination of the two chaperone systems (GroELGroES and TF) supported the folding of $\mathrm{PhaR}_{\mathrm{YB} 4}$ and PhaCYB4. These results suggest that the utilization of chaperone proteins is a valuable approach to enhance the formation of active PHA synthase and the productivity of $3 \mathrm{HBO}$.
\end{abstract}

Keywords: oligomer; polyhydroxyalkanoate (PHA); PHA synthase; secretory production; chaperones

\section{Introduction}

Polyhydroxyalkanoates (PHAs) are biodegradable plastics that are synthesized by various microorganisms [1-3]. Depending on monomer structure, PHAs can be categorized into three groups: short-chain-length PHAs (SCL-PHAs), containing 3-5 carbon atoms in the monomer; medium-chain-length PHAs (MCL-PHAs), containing 6-14 carbon atoms in the monomer; and SCL-MCL-PHAs, containing both SCL and MCL monomer units. PHA synthase is a key enzyme in the polymerization of PHA. PHA synthases can be divided into four classes according to their substrate specificities and subunit compositions [4]. Whereas class I and II PHA synthases are composed of single subunits of PhaC, class III and IV PHA synthases are composed of two heterosubunits, with PhaE and PhaC forming PhaEC and PhaR, and PhaC forming PhaRC [5]. Regarding substrate specificity, class I, III, and IV PHA synthases prefer SCL monomers as substrates, whereas class II PHA synthases are specific to MCL monomers. Attempts have been made to synthesize PHAs with favorable properties 
using various natural and engineered PHA synthases [6-8]. The homopolymer poly[(R)-3hydroxybutyrate] [P(3HB)], the most common SCL-PHA, is stiff and brittle, which limits its range of applications. $\mathrm{P}(3 \mathrm{HB}-c o-3-h y d r o x y h e x i a n o a t e) ~[\mathrm{P}(3 \mathrm{HB}-c o-3 \mathrm{HHx})]$ [9]; $\mathrm{P}(3 \mathrm{HB}-c o-$ 3-hydroxyalkanoate), consisting of 3HA units of $\mathrm{C}_{6}-\mathrm{C}_{12}$ [10]; P(D-lactate-co-3HB) [P(LA-co3HB)], a D-lactate-based polymer [11]; and MCL-PHA homopolymers [12] have improved properties, exhibiting transparency and flexibility.

In recent studies, the secretory production of low-molecular-weight D-lactate-based polymers and $\mathrm{P}(3 \mathrm{HB})$ polymers, referred to as D-lactate-based oligomers (D-LAOs) and $3 \mathrm{HB}$ oligomers (3HBOs), respectively, was demonstrated using Escherichia coli heterologously expressing PHA synthases [13-18]. Unlike polymer production in cells, secretory production is a continuous process because of the lack of a cell volume limitation. In particular, $3 \mathrm{HBOs}$ are found in nature, for example, as a spider sex pheromone and a growth-promoting factor for bacteria [19-22]. Recently, the antibacterial activity of a 3HBO and an application of this oligomer (as a textile fiber) were also reported [21,23]. 3HBOs are expected to have utility as bioactive compounds and macromonomers for various polymers, such as polyurethanes $[17,24]$.

Our group first developed an artificial $3 \mathrm{HBO}$ production system using recombinant $E$. coli. The recombinant $E$. coli strain had a gene cassette consisting of the $\beta$-ketothiolase (phaA) gene, the NADPH-dependent acetoacetyl-CoA reductase gene (phaB), and the PHA synthase gene (phaC). In particular, PHA synthases derived from Bacillus cereus YB-4 (PhaRC $\mathrm{Y}_{\mathrm{YB} 4}$ ) and from Aeromonas caviae $\left(\mathrm{PhaC}_{\mathrm{Ac}}\right.$ ) were superior in terms of $3 \mathrm{HBO}$ productivity [16]. To date, $3 \mathrm{HBO}$ generation has been observed in the presence of host-produced (endogenous) and/or supplemented (exogeneous) alcohols. This phenomenon indicates that i) alcohols are frequently added to the carboxy terminus of oligomers in the polymerization process via PHA synthases and lead to the generation of new oligomer chains (termed the chain transfer reaction) and ii) alcohols degrade elongated polymer chains via specific PHA synthases such as PhaRC $\mathrm{YB}_{\mathrm{Y} 4}$ under monomer-depleted conditions in the late phase of cultivation (termed the alcoholysis reaction) $[13,16]$. In the process of alcoholysis, since intracellular $\mathrm{P}(3 \mathrm{HB})$ is gradually degraded, a decrease in the molecular weight of $\mathrm{P}(3 \mathrm{HB})$ and the generation of $3 \mathrm{HBO}$ are simultaneously observed $[25,26]$. Through these two reactions, the secretory production of $3 \mathrm{HBO}$ end-capped with host-produced ethanol [16] and $3 \mathrm{HBO}$ end-capped with supplemented diethylene glycol (DEG) [17] has been reported.

In this study, we focused on the expression level of PHA synthase to establish an efficient $3 \mathrm{HBO}$ production system. In a previous study of $\mathrm{P}(3 \mathrm{HB})$ (polymer) production, when PHA synthase was highly expressed, an increase in the polymer amount was observed because of an increase in the polymerization starting point $[27,28]$. In parallel, higher expression of PHA synthase led to a decrease in the molecular weight of $\mathrm{P}(3 \mathrm{HB})$ due to the competition for the $3 \mathrm{HB}$ monomer by additional PHA synthases. With regard to the $3 \mathrm{HBO}$ production system, we predicted that higher expression of PHA synthase would enhance the $3 \mathrm{HBO}$ amount based on the same principle. To improve the expression level of PHA synthase, we attempted to utilize the major molecular chaperones in E. coli. Generally, a majority of proteins must be correctly folded into specific three-dimensional shapes for functionalization. However, nascent polypeptide chains are prone to misfolding and aggregation. Molecular chaperones prevent protein misfolding and assist in the refolding of misfolded proteins. Previous studies have shown that PHA synthases easily form inclusion bodies when overexpressed in E. coli and that the use of molecular chaperones is effective for the formation of active PHA synthases [29]. One of the major chaperones, trigger factor (TF), binds to the bacterial ribosome and interacts with emerging nascent polypeptide chains $[30,31]$. Another chaperone, GroEL, and its cofactor GroES, promote protein folding by sequestering nonnative polypeptides in a cage-like structure [32,33]. Here, we report the effect of chaperone coexpression on $3 \mathrm{HBO}$ production. 


\section{Materials and Methods}

\subsection{Bacterial Strains and Plasmids}

The bacterial strains and plasmids used in this study are listed in Table 1. pGEMphaRC ${ }_{\mathrm{YB} 4} A B$ [34] was introduced into E. coli BW25113 or its mutant strain lacking the alcohol dehydrogenase gene (BW25113 $\triangle a d h E$ ) for $3 \mathrm{HBO}$ or $\mathrm{P}(3 \mathrm{HB})$ production. The chaperone plasmid pG-Tf2 containing GroEL-GroES/TF genes (groEL, groES, and tig) was selected from the Chaperone Plasmid Set (Takara Bio Inc., Shiga, Japan) according to a previous study [29]. In pG-Tf2, the groEL, groES, and tig genes are located downstream of the Pzt1 (tet) promoter and can be expressed by induction of tetracycline. Another chaperone plasmid, pG-KJE8, containing the groEL and groES genes, was also used in subsequent assays. pET15b-phaR $\mathrm{YB}_{\mathrm{Y} 4}$ or pET15b-phaC $\mathrm{C}_{\mathrm{YB} 4}$ [25] was introduced into E. coli BL21(DE3) for the expression of $\mathrm{PhaR}_{\mathrm{YB} 4}$ or $\mathrm{PhaC}_{\mathrm{YB} 4}$, respectively. To maintain the plasmids within the cells, $100 \mathrm{mg} / \mathrm{L}$ ampicillin (for pGEM-phaRC ${ }_{\mathrm{YB} 4} A B$ ), $20 \mathrm{mg} / \mathrm{L}$ chloramphenicol (for pG-KJE8 and pG-Tf2), and $50 \mathrm{mg} / \mathrm{L}$ carbenicillin (for pET15b-phaR ${ }_{\mathrm{YB} 4}$ and pET15b-phaC $\mathrm{C}_{\mathrm{YB} 4}$ ) were added to the medium as appropriate.

Table 1. Strains and plasmids used in this study.

\begin{tabular}{|c|c|c|}
\hline Strain or Plasmid & Relevant Characteristics & Reference/Source \\
\hline \multicolumn{3}{|l|}{ Strains } \\
\hline Escherichia coli BW25113 & rrnBT14 $\Delta l a c Z W J 16$ hsdR514 $\triangle a r a B A D A H 33$ & [35] \\
\hline E. coli BW25113 $\triangle a d h E$ & BW25113, $\triangle a d h E:: F R T-K m-F R T$ & [35] \\
\hline E. coli BL21(DE3) & $\mathrm{F}^{-}$ompT hsdS $S_{\mathrm{B}}\left(\mathrm{r}_{\mathrm{B}}^{-} \mathrm{m}_{\mathrm{B}}^{-}\right)$gal dcm & Novagen \\
\hline \multicolumn{3}{|l|}{ Plasmids } \\
\hline pGEM-phaRC ${ }_{\mathrm{YB} 4} A B$ & $\begin{array}{l}\text { pGEM-T derivative; pha } a_{\mathrm{Re}} \text { promoter, phaRC } C_{\mathrm{YB} 4} \text { from B. cereus } \mathrm{YB}-4 \text {, } \\
\text { and phaAB } B_{\mathrm{Re}} \text { from Ralstonia eutropha (Cupriavidus necator), } \mathrm{Ap}^{\mathrm{r}}\end{array}$ & [34] \\
\hline pG-Tf2 & Expression vector for GroEL/GroES/Tf; $p z t 1$ promoter; $\mathrm{Cm}^{\mathrm{r}}$ & Takara Bio. \\
\hline pG-KJE8 & $\begin{array}{l}\text { Expression vector for GroEL/GroES with pzt1 promoter; DnaK, DnaJ, } \\
\text { GrpE with araB promoter; } \mathrm{Cm}^{\mathrm{r}}\end{array}$ & Takara Bio. \\
\hline pET15b-phaR Үв $4_{1}$ & $\begin{array}{c}\text { pET15b derivative; expression of } \mathrm{N} \text {-terminal His-tagged phaR } R_{\mathrm{YB} 4} \\
\text { from } B \text {. cereus } \mathrm{YB}-4, \mathrm{Ap}^{\mathrm{r}}\end{array}$ & [25] \\
\hline pET15b-phaC & $\begin{array}{c}\text { pET15b derivative; expression of } \mathrm{N} \text {-terminal His-tagged } p h a \mathrm{C}_{\mathrm{YB} 4} \\
\text { from } B \text {. cereus } \mathrm{YB}-4, \mathrm{Ap}^{\mathrm{r}}\end{array}$ & [25] \\
\hline
\end{tabular}

\subsection{Culture Conditions for $3 \mathrm{HBO}$ Production}

For 3HBO production, four strains, namely, E. coli BW25113 or BW25113 $\Delta a d h E$ harboring pGEM-phaRC ${ }_{\mathrm{YB} 4} A B$ or pGEM-phaR $C_{\mathrm{YB} 4} A B+$ pG-Tf2, were prepared. Each transformant was cultivated in $1.7 \mathrm{~mL}$ of Luria-Bertani (LB) medium $(10 \mathrm{~g} / \mathrm{L} \mathrm{NaCl}, 10 \mathrm{~g} / \mathrm{L}$ tryptone, and $5 \mathrm{~g} / \mathrm{L}$ yeast extract) containing the appropriate antibiotics at $30^{\circ} \mathrm{C}$ for $16 \mathrm{~h}$ as a preculture. One milliliter of the preculture was inoculated into a $500 \mathrm{~mL}$ apple-shaped flask with $100 \mathrm{~mL}$ of LB medium containing glucose $(20 \mathrm{~g} / \mathrm{L})$ and the appropriate antibiotics. For strains harboring pG-Tf2, tetracycline $(5 \mu \mathrm{g} / \mathrm{L})$ was added as an inducer for chaperones at the beginning of cultivation. Cells were cultivated at $30^{\circ} \mathrm{C}$ for $48 \mathrm{~h}(130$ strokes $/ \mathrm{min})$, harvested by centrifugation $\left(10,000 \times g, 10 \mathrm{~min}, 24^{\circ} \mathrm{C}\right)$, washed twice with pure water and lyophilized. The culture supernatant was collected for measuring the $3 \mathrm{HBO}$ and $3 \mathrm{HB}$ levels.

\subsection{Quantification of Extracellular 3HBOs/3HB, Extracellular Ethanol, Intracellular $3 \mathrm{HBO}$ and $P(3 H B)$}

The concentrations of extracellular $3 \mathrm{HBOs} / 3 \mathrm{HB}$ and intracellular $3 \mathrm{HBO}$ sere determined by an enzyme assay as described previously [16,17]. In the same way, the concentration of extracellular ethanol was measured by an enzyme assay using F-kit Ethanol (J. K. International, Tokyo, Japan). The total amounts of $\mathrm{P}(3 \mathrm{HB})$ and intracellular $3 \mathrm{HBOs}$ were determined by gas chromatography (GC) using a GC2030 instrument (Shimadzu, Kyoto, Japan) equipped with a flame ionization detector (FID). Approximately $15 \mathrm{mg}$ of lyophilized cells was methanolized with 15\% (v/v) sulfuric acid as previously described [36]. 
The amount of $\mathrm{P}(3 \mathrm{HB})$ was calculated by subtracting the amount of intracellular $3 \mathrm{HBO}$ determined by the above enzyme assay.

\subsection{Extraction of $3 \mathrm{HBO}$ and ESI-TOF-MS Analysis}

For the assay of the molecular weight (polymerization degree) of 3HBOs, extracellular $3 \mathrm{HBO}$ s were extracted from cell-free (filtered) culture supernatants. First, the cell-free supernatant was added to an equivalent volume of chloroform, and the mixture was stirred for at least $1 \mathrm{~h}$. After cessation of stirring, the mixture was allowed to stand until two layers were clearly observed. The chloroform layer was recovered, and an equivalent volume of pure water was added to and mixed with the extract to remove the medium components and $3 \mathrm{HB}$ monomer. This washing step using pure water was repeated twice. Then, the recovered chloroform layer was dried to obtain an extracellular $3 \mathrm{HBO}$ sample. Intracellular $3 \mathrm{HBO}$ were extracted from the dried cells by soaking in methanol. After forceful centrifugation, the cell debris was removed by a polytetrafluoroethylene (PTFE) filter, and intracellular $3 \mathrm{HBO}$ samples were obtained. The $3 \mathrm{HBO}$ samples were dissolved in methanol and filtered before being subjected to electrospray ionization-time of flight-mass spectrometry (ESI-TOF-MS) analysis.

\subsection{Purification of $P(3 H B)$ and GPC Analysis}

The $\mathrm{P}(3 \mathrm{HB})$ accumulated in the cells was extracted with chloroform and purified by reprecipitation with methanol as described previously [16]. The molecular weights $\left(M_{n}\right.$ and $\left.M_{\mathrm{w}}\right)$ and molecular weight distribution $\left(M_{\mathrm{w}} / M_{\mathrm{n}}\right)$ were determined by gel permeation chromatography (GPC). GPC measurements were performed at $40^{\circ} \mathrm{C}$ using a Shimadzu 20A GPC system and a 20A refractive index detector (Shimadzu, Kyoto, Japan) equipped with a Shimadzu GPC-80MC column joined to two Shodex K806M columns (Showa Denko $\mathrm{KK}$, Tokyo, Japan). Chloroform was used as the mobile phase at a flow rate of $0.8 \mathrm{~mL} / \mathrm{min}$. Samples for GPC analysis were prepared at a $\mathrm{P}(3 \mathrm{HB})$ concentration of $1.0 \mathrm{mg} / \mathrm{mL}$ and passed through a $0.2-\mu \mathrm{m}$ PTFE filter. Then, $100 \mu \mathrm{L}$ of each sample was injected into the GPC system. Low-polydispersity polystyrene standards were used to generate a calibration curve, and the relative molecular weight of $\mathrm{P}(3 \mathrm{HB})$ was calculated based on the calibration curve.

\subsection{PHA Synthase Activity Assay}

To measure the activity of PHA synthase during the production of $3 \mathrm{HBOs}$, cells at $24 \mathrm{~h}$ of cultivation were collected, washed with $50 \mathrm{mM} \mathrm{NaPi}$ buffer, and stored at $-80^{\circ} \mathrm{C}$ until the activity assay. The cells were resuspended in $50 \mathrm{mM} \mathrm{NaPi}$ buffer, disrupted by sonication ( 10 times $\times 30 \mathrm{~s}$ ), and centrifuged at $1500 \times \mathrm{g}$ for $5 \mathrm{~min}$ at $4{ }^{\circ} \mathrm{C}$ to obtain crude extract containing PHA synthase, which was bound to PHA granules. The activity of PHA synthase was assayed by measuring the decrease in absorbance at $236 \mathrm{~nm}$ $\left(\varepsilon=4500\left[\mathrm{M}^{-1} \mathrm{~cm}^{-1}\right]\right)$ caused by cleavage of the thioester bond of (R)-3HB-CoA [37]. The reaction was initiated by the addition of $20 \mu \mathrm{g}$ of crude protein into the reaction buffer, consisting of $50 \mathrm{mM} \mathrm{NaPi}$ buffer $(\mathrm{pH} 7.0)$ and $(R)-3 \mathrm{HB}-\mathrm{CoA}(100 \mu \mathrm{M})$. The specific activity ( $\mathrm{U} / \mathrm{mg}$-protein) of PHA synthase was determined using the maximum velocities of each reaction. (R)-3HB-CoA was prepared as described previously [16].

\subsection{Expression of PhaR $\mathrm{RB}_{Y 4}$ and $\mathrm{PhaC}_{Y B 4}$ with Molecular Chaperones}

To evaluate the effect of molecular chaperones on the expression of $\mathrm{PhaR}_{\mathrm{YB} 4}$ and $\mathrm{PhaC}_{\mathrm{YB} 4}$, six transformants were prepared by transforming E. coli BL21(DE3) with pET15b-phaR $\mathrm{YB}_{\mathrm{YB}}$, pET15b-phaR YB4$_{4}+$ pG-KJE8 (encoding the GroEL-GroES genes), pET15b-phaR YB4 $_{4}+$ pG-Tf2 (encoding the GroEL-GroES and TF genes), pET15b-pha $\mathrm{C}_{\mathrm{YB} 4}, \mathrm{pET15b}-\mathrm{pha} \mathrm{C}_{\mathrm{YB} 4}+\mathrm{pG}-\mathrm{KJE} 8$ or $\mathrm{pET15b}-\mathrm{pha} \mathrm{C}_{\mathrm{YB} 4}+\mathrm{pG}-\mathrm{Tf} 2$. The resulting six transformants were cultivated in $1.7 \mathrm{~mL}$ of LB medium. The preculture was inoculated into a $500 \mathrm{~mL}$ apple-shaped flask with $100 \mathrm{~mL}$ of LB medium with antibiotics. To generate chaperone proteins before $\mathrm{PhaR}_{\mathrm{YB} 4}$ and $\mathrm{PhaC}_{\mathrm{YB} 4}$ expression, the inducer for chaperones, tetracycline ( 5 or $10 \mu \mathrm{g} / \mathrm{L}$ ), was added to the medium at the 
beginning of cultivation. Cells were cultivated with shaking (130 strokes $/ \mathrm{min})$ at $30{ }^{\circ} \mathrm{C}$ until the optical density at $600 \mathrm{~nm}\left(\mathrm{OD}_{600}\right)$ reached $0.4-0.6$. Then, $100 \mu \mathrm{L}$ of $0.1 \mathrm{M}$ isopropyl- $\beta-\mathrm{D}-$ 1-thiogalactopyranoside (IPTG) was added to the medium (final concentration of $0.1 \mathrm{mM}$ ), and the culture was grown at $20^{\circ} \mathrm{C}$ for $8 \mathrm{~h}$ with shaking. The cells were harvested, washed with $50 \mathrm{mM}$ sodium phosphate buffer ( $\mathrm{NaPi}, \mathrm{pH} 7.0)$, and stored at $-80^{\circ} \mathrm{C}$. Subsequently, the cells were resuspended in the same buffer, disrupted by sonication (10 times $\times 30 \mathrm{~s}$ ), and centrifuged at $20,400 \times g$ for $20 \mathrm{~min}$ at $4{ }^{\circ} \mathrm{C}$. The supernatant (soluble protein fraction) and the pellet (insoluble fraction) were resuspended in $50 \mathrm{mM} \mathrm{NaPi}$ buffer, and the protein concentration in each fraction was determined using a Qubit ${ }^{\text {TM }}$ Protein Assay Kit (Invitrogen, Carlsbad, CA, USA) according to the manufacturer's instructions. The expression of PhaR $\mathrm{PB}_{\text {Y }}$ and PhaC $\mathrm{YB}_{\text {Y }}$ was confirmed by sodium dodecyl sulfate-polyacrylamide gel electrophoresis (SDS-PAGE) using 10 and $12.5 \mathrm{wt} \%$ gels, respectively. Ten micrograms of total protein was loaded per sample, and the gels were stained with Coomassie Brilliant Blue (CBB). The expression levels of $\mathrm{PhaR}_{Y \mathrm{~B} 4}$ and $\mathrm{PhaC}_{Y \mathrm{~B} 4}$ were determined using ImageJ software (https:/ /imagej.nih.gov/ij/index.html (accessed on 27 January 2022)).

\section{Results}

\subsection{Effect of Chaperones on $3 H B O$ Production}

To examine the effect of chaperones on $3 \mathrm{HBO}$ production, E. coli BW25113 harboring the plasmid pGEM-phaRC ${ }_{\mathrm{YB} 4} A B$ alone or the plasmid pair pGEM-phaRC ${ }_{\mathrm{YB} 4} A B+\mathrm{pG}-\mathrm{Tf} 2$ was grown in LB medium containing $20 \mathrm{~g} / \mathrm{L}$ glucose (Table 2). As shown in Table 2, the total residual cell mass (RCM) and $3 \mathrm{HB}$ level (intracellular $\mathrm{P}(3 \mathrm{HB})+$ intracellular $3 \mathrm{HBOs}$ + extracellular 3HBOs + extracellular 3HB) in the control strain $(10.08 \pm 0.06 \mathrm{~g} / \mathrm{L})$ and chaperone-expressing strain $(10.07 \pm 0.03 \mathrm{~g} / \mathrm{L})$ were equal. By comparison, the total amount of 3HBOs (extracellular and intracellular) increased 1.8-fold upon coexpression of the GroEL-GroES/TF chaperones (control, $0.92 \pm 0.05 \mathrm{~g} / \mathrm{L} ;+\mathrm{pG}-\mathrm{Tf} 2,1.75 \pm 0.08 \mathrm{~g} / \mathrm{L}$ ), and the amount of $\mathrm{P}(3 \mathrm{HB})$ decreased from $7.41 \pm 0.09 \mathrm{~g} / \mathrm{L}$ to $6.08 \pm 0.15 \mathrm{~g} / \mathrm{L}$. In addition, the molecular weight $\left(M_{\mathrm{n}}\right.$ and $\left.M_{\mathrm{w}}\right)$ of $\mathrm{P}(3 \mathrm{HB})$ isolated from the strain coexpressing chaperones was lower than that in the control strain, as previously reported [16,29]. The polydispersity (defined as the ratio of $M_{\mathrm{w}}$ to $M_{\mathrm{n}}$ ) was not changed by the expression of chaperones (Table 2, Figure S1A).

Table 2. Effect of coexpression of the chaperone plasmid pG-Tf2 on $3 \mathrm{HBO}$ production in recombinant E. coli BW2511 harboring pGEM-phaR ${ }_{\mathrm{YB} 4} A B$.

\begin{tabular}{|c|c|c|c|c|c|c|c|c|c|}
\hline \multirow{2}{*}{ Plasmid } & \multirow{2}{*}{$\begin{array}{c}\text { Dry Cell } \\
\text { Weight } \\
\text { (g/L) }\end{array}$} & \multirow{2}{*}{$\begin{array}{c}\text { Residual } \\
\text { Cell Mass } \\
(\mathrm{g} / \mathrm{L})\end{array}$} & \multirow{2}{*}{$\begin{array}{c}\text { Intracellular } \\
\text { P(3HB) } \\
(\mathrm{g} / \mathrm{L})\end{array}$} & \multirow{2}{*}{$\begin{array}{c}\text { Intracellular } \\
\text { 3HBOs } \\
(\mathrm{g} / \mathrm{L})\end{array}$} & \multirow{2}{*}{$\begin{array}{c}\text { Extracellular } \\
\text { 3HBOs } \\
(\mathrm{g} / \mathrm{L})\end{array}$} & \multirow{2}{*}{$\begin{array}{c}\text { Extracellular } \\
\text { 3HB } \\
(\mathrm{g} / \mathrm{L})\end{array}$} & \multicolumn{3}{|c|}{ Molecular Weight of $\mathrm{P}(3 \mathrm{HB})$} \\
\hline & & & & & & & $M_{n}\left(\times 10^{4}\right)$ & $M_{w}\left(\times 10^{4}\right)$ & $M_{w} / M_{n}$ \\
\hline $\begin{array}{c}\text { pGEM- } \\
\text { phaRC } C_{\mathrm{YB} 4} A B \\
\text { pGEM- }\end{array}$ & $9.40 \pm 0.05$ & $1.72 \pm 0.01$ & $7.41 \pm 0.09$ & $0.27 \pm 0.03$ & $0.65 \pm 0.04$ & $0.03 \pm 0.00$ & $2.3 \pm 0.0$ & $5.0 \pm 0.1$ & 2.2 \\
\hline $\begin{array}{c}\text { phaRC } C_{\mathrm{YB} 4} A B \\
+ \text { pG-Tf2 }\end{array}$ & $8.81 \pm 0.08$ & $2.22 \pm 0.12$ & $6.08 \pm 0.15$ & $0.50 \pm 0.04$ & $1.24 \pm 0.08$ & $0.03 \pm 0.00$ & $1.7 \pm 0.1$ & $3.5 \pm 0.0$ & 2.2 \\
\hline
\end{tabular}

Cells were cultivated in LB medium containing $20 \mathrm{~g} / \mathrm{L}$ glucose and the appropriate antibiotics at $30{ }^{\circ} \mathrm{C}$ for $48 \mathrm{~h}$ The amount and molecular weight of $\mathrm{P}(3 \mathrm{HB})$ were determined by GC and GPC analyses, respectively. The concentrations of intracellular/extracellular $3 \mathrm{HBO}$ and $3 \mathrm{HB}$ were measured by an enzyme assay. The results are the averages \pm standard errors from three independent experiments.

The ESI-TOF-MS charts (Figure 1) show the molecular weights of the extracellular and intracellular $3 \mathrm{HBO}$ s produced by the chaperone-expressing strain. The molecular weights of extracellular (Figure 1A) and intracellular 3HBOs (Figure 1B) were 200-800 (2-8 mers) and 500-1600 (6-17 mers), respectively. The peak interval, $m / z$ 86, indicates a repeating $3 \mathrm{HB}$ unit, and the $m / z$ of each peak matches that of sodium-adducted $3 \mathrm{HBOs}$ end-capped with ethanol, as previously reported [16,17]. As shown in Figure 1, the peaks for the extracellular and intracellular 3HBOs corresponded to 5 and 8 mers, respectively, and the spectra were the same as those of the strain without chaperones (data not shown). 

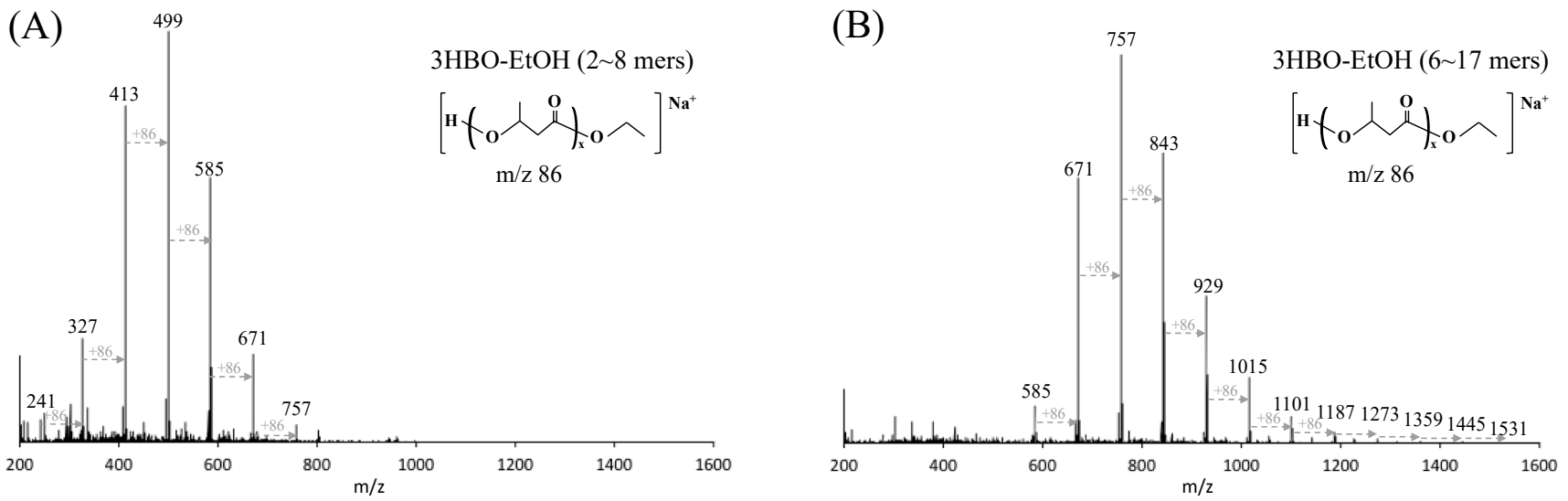

Figure 1. ESI-TOF-MS charts of extracellular (A) and intracellular (B) 3HBOs. 3HBOs were purified from the culture supernatant or cells of $E$. coli BW25113 harboring pGEM-phaRC ${ }_{\mathrm{YB} 4} A B+$ pG-Tf2 after $48 \mathrm{~h}$ of cultivation. ESI-TOF-MS was performed in positive mode with an applied voltage of $120 \mathrm{~V}$.

To investigate the relationship between the increased yield of $3 \mathrm{HBOs}$ and the proportion of the active form of PHA synthase, an in vitro enzyme assay was performed. The enzyme activity of the chaperone-expressing strain was 3.0-fold higher than that of the control strain (Figure 2). SDS-PAGE analysis also showed a higher abundance of PhaRYB4 in the coexpression strain (data not shown). By comparison, the ethanol concentration in the culture medium was 1.5 -fold higher than that in the chaperone-nonexpressing strain (control, $0.46 \pm 0.02 \mathrm{~g} / \mathrm{L} ;+$ pG-Tf2, $0.68 \pm 0.02 \mathrm{~g} / \mathrm{L}$ ).

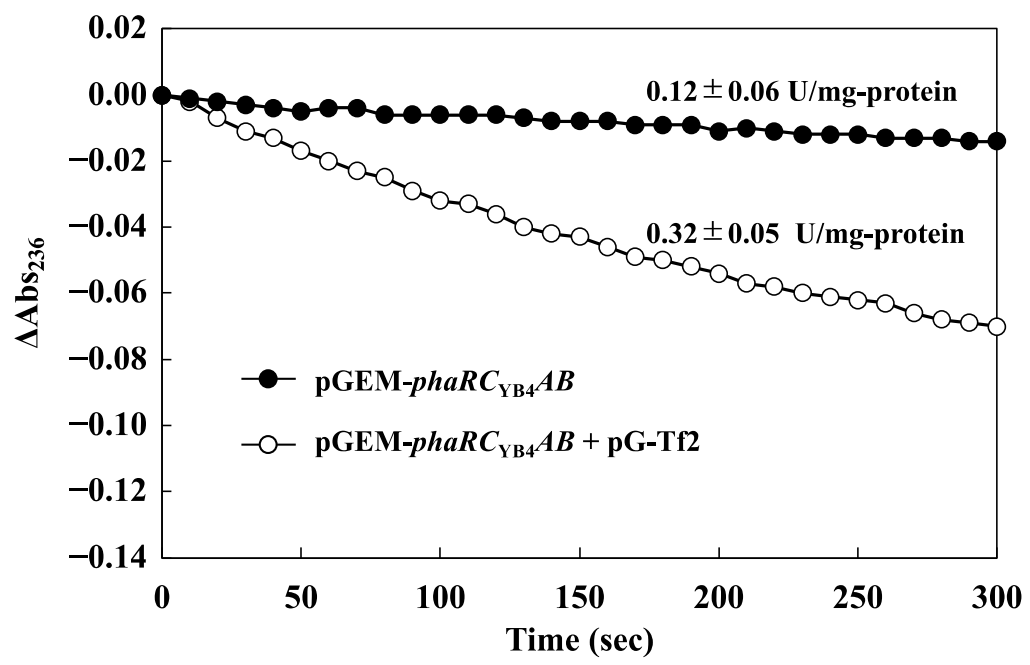

Figure 2. Specific activity of PhaRC $\mathrm{YB}_{4}$ with/without the chaperone plasmid pG-Tf2. Specific activities were determined by using the change in absorbance at $236 \mathrm{~nm}$ at maximum velocity.

\subsection{Time Course Pattern of 3 HBO Production with Coexpression of Molecular Chaperones}

To trace the cultivation of the strain with or without chaperones, time course data were collected (Figure 3). $3 \mathrm{HBO}$ production in the two strains increased with culture time (Figure 3A). By comparison, $\mathrm{P}(3 \mathrm{HB}$ ) production peaked at $24 \mathrm{~h}$ (Control, $8.09 \mathrm{~g} / \mathrm{L}$; +pG-Tf2, $7.23 \mathrm{~g} / \mathrm{L}$ ) and decreased during the $24-48 \mathrm{~h}$ phase. This phenomenon suggests that the produced polymer was converted to an oligomer by an alcoholysis reaction in the later phase of cultivation, as reported previously [17]. By comparing the two strains, it was confirmed that $3 \mathrm{HBO}$ production in the chaperone-expressing strain was higher than that in the control strain at all time points. This result suggests that the higher expression of PHA synthase in the chaperone-expressing strain enhanced both the chain transfer reaction (mainly in the growth phase) and the alcoholysis reaction (mainly in the stationary phase) 
and generated many more oligomers. The molecular weight of $\mathrm{P}(3 \mathrm{HB})$ decreased with culture time (Figure $3 \mathrm{~B}$ ). As described in the Introduction section, when the expression of PHA synthase is higher, the molecular weight of $\mathrm{P}(3 \mathrm{HB})$ is lower due to competition for $3 \mathrm{HB}$ monomers. Therefore, the molecular weight for the chaperone-expressing strain with more PHA synthases was relatively low at the beginning of cultivation and further decreased by the alcoholysis reaction.

(A)

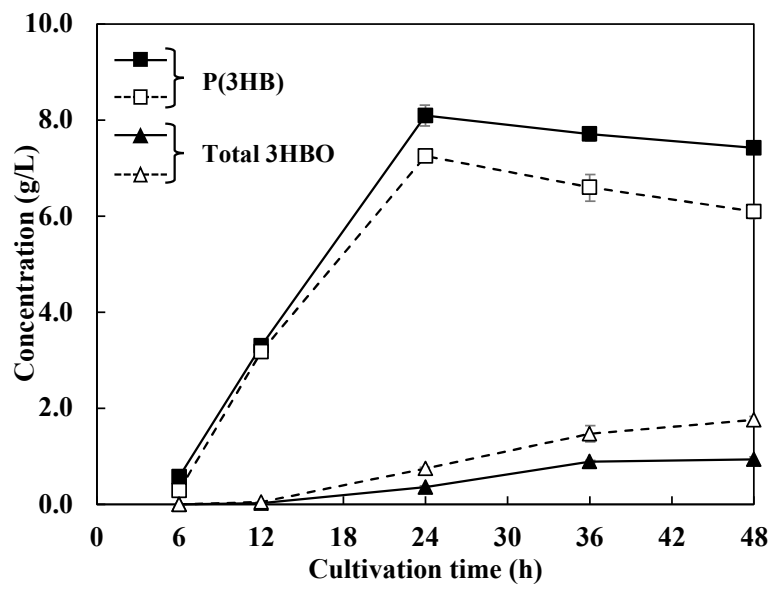

(B)

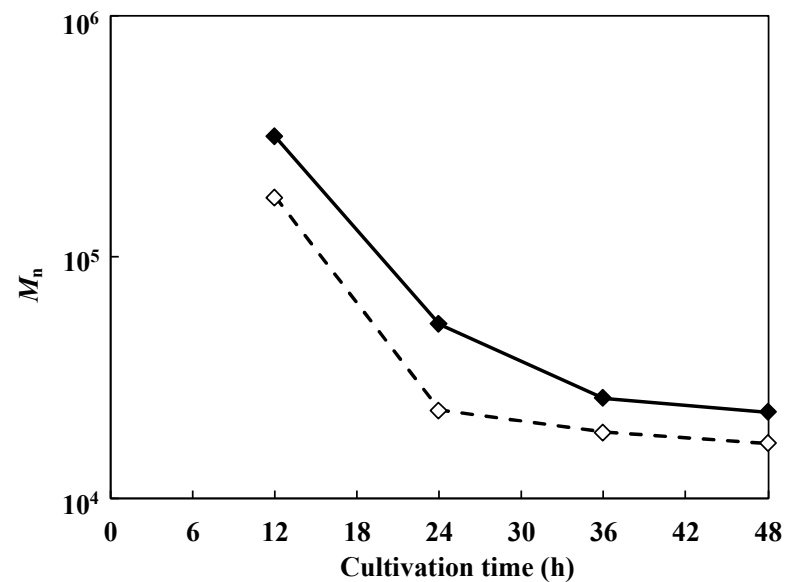

Figure 3. Time course data for the cultivation of recombinant E. coli BW25113 harboring pGEMphaRC $C_{\mathrm{YB} 4} A B$ (solid line) or pGEM-phaRC $\mathrm{YB}_{4} A B+$ pG-Tf2 (broken line). (A) Concentrations of $\mathrm{P}(3 \mathrm{HB})$ and total $3 \mathrm{HBO}$ (intracellular 3HBOs + extracellular 3HBOs). (B) Number-average molecular weight of $\mathrm{P}(3 \mathrm{HB})(12-48 \mathrm{~h}$ of cultivation). Purified $\mathrm{P}(3 \mathrm{HB})$ at $6 \mathrm{~h}$ of cultivation could not be analyzed because it was present in only trace amount.

\subsection{Production of 3HBOs in Non-Ethanol-Producing E. coli with Coexpression of Molecular Chaperones}

To clearly define the effect of high expression of PHA synthase on $3 \mathrm{HBO}$ production, host-produced ethanol, which functions as a substrate for chain transfer reactions and alcoholysis reactions, was removed from the culture using the non-ethanol-producing E. coli strain BW25113 $\Delta a d h E$. As shown in Table 3, when the $\triangle a d h E$ strain was used, the production level of $3 \mathrm{HBO}$ was reduced by approximately $1 / 5$ compared to that in the WT strain (Table 2), indicating that chain transfer and alcoholysis reactions using host-produced ethanol were repressed, as expected. The ethanol concentration in the culture supernatant was at trace levels regardless of the presence of chaperones. The total amount of $3 \mathrm{HBOs}$ from the $\triangle a d h E$ strains increased 2.0-fold when the chaperones were expressed (Control, $0.18 \pm 0.01 \mathrm{~g} / \mathrm{L} ;+$ pG-Tf2, $0.38 \pm 0.02 \mathrm{~g} / \mathrm{L})$. In addition, the activity assay of the $\triangle a d h E$ strains showed that the expression level of PHA synthase increased 2.3-fold upon chaperone expression (Control, $0.19 \pm 0.05 \mathrm{U} / \mathrm{mg}$-protein; +pG-Tf2, $0.44 \pm 0.10 \mathrm{U} / \mathrm{mg}$-protein). The molecular weight $\left(M_{\mathrm{n}}\right.$ and $\left.M_{\mathrm{w}}\right)$ of $\mathrm{P}(3 \mathrm{HB})$ isolated from the chaperone-expressing $\triangle a d h E$ strain was lower than that in the nonexpressing $\triangle a d h E$ strain and the chaperoneexpressing/nonexpressing WT strains. By comparison, in the case of $\triangle a d h E$ strains, the bimodal distribution of the $\mathrm{P}(3 \mathrm{HB})$ molecular weight was confirmed (Figure S1B), suggesting that the trace level of ethanol produced by the $\triangle a d h E$ strains acted as the substrate for chain transfer and alcoholysis reactions. 
Table 3. Effect of coexpression of the chaperone plasmid pG-Tf2 on $3 \mathrm{HBO}$ production in recombinant E. coli BW2511 $\triangle a d h E$ harboring pGEM-phaRC ${ }_{\mathrm{YB} 4} A B$.

\begin{tabular}{|c|c|c|c|c|c|c|c|c|c|}
\hline \multirow{2}{*}{ Plasmid } & \multirow{2}{*}{$\begin{array}{l}\text { Dry Cell } \\
\text { Weight } \\
\text { (g/L) }\end{array}$} & \multirow{2}{*}{$\begin{array}{l}\text { Residual } \\
\text { Cell Mass } \\
\text { (g/L) }\end{array}$} & \multirow{2}{*}{$\begin{array}{c}\text { Intracellular } \\
\text { P(3HB) } \\
\text { (g/L) }\end{array}$} & \multirow{2}{*}{$\begin{array}{c}\text { Intracellular } \\
\text { 3HBOs } \\
\text { (g/L) }\end{array}$} & \multirow{2}{*}{$\begin{array}{c}\text { Extracellular } \\
\text { 3HBOs } \\
(\mathrm{g} / \mathrm{L})\end{array}$} & \multirow{2}{*}{$\begin{array}{c}\text { Extracellular } \\
\text { 3HB } \\
(\mathrm{g} / \mathrm{L})\end{array}$} & \multicolumn{3}{|c|}{ Molecular Weight of $\mathrm{P}(3 \mathrm{HB})$} \\
\hline & & & & & & & $M_{n}\left(\times 10^{4}\right)$ & $M_{w}\left(\times 10^{4}\right)$ & $M_{w} / M_{n}$ \\
\hline $\begin{array}{c}\text { pGEM- } \\
\text { phaRC }{ }_{\text {YBA }} A B \\
\text { pGEM- }\end{array}$ & $9.67 \pm 0.02$ & $1.42 \pm 0.09$ & $8.24 \pm 0.07$ & $0.01 \pm 0.00$ & $0.18 \pm 0.01$ & $0.04 \pm 0.00$ & $20.4 \pm 1.3$ & $151.9 \pm 5.4$ & 7.5 \\
\hline $\begin{array}{c}\text { phaRC } C_{\mathrm{YB} 4} A B \\
+ \text { pG-Tf2 }\end{array}$ & $9.77 \pm 0.02$ & $2.03 \pm 0.23$ & $7.73 \pm 0.21$ & $0.02 \pm 0.00$ & $0.37 \pm 0.02$ & $0.03 \pm 0.00$ & $9.4 \pm 0.5$ & $76.5 \pm 5.8$ & 8.2 \\
\hline
\end{tabular}

Cells were cultivated in LB medium containing $20 \mathrm{~g} / \mathrm{L}$ glucose and the appropriate antibiotics at $30{ }^{\circ} \mathrm{C}$ for $48 \mathrm{~h}$ The amount and molecular weight of $\mathrm{P}(3 \mathrm{HB})$ were determined by GC and GPC analyses, respectively. The concentrations of intracellular/extracellular $3 \mathrm{HBO}$ and $3 \mathrm{HB}$ were measured by an enzyme assay. The results are the averages \pm standard errors from three independent experiments.

\subsection{Effect of Chaperones on PhaR $\mathrm{YB}_{B 4}$ and $\mathrm{PhaC}_{Y B 4}$ Expression}

To determine the expression levels of $\mathrm{PhaR}_{\mathrm{YB} 4}$ and $\mathrm{PhaC}_{\mathrm{YB} 4}$ with/without chaperones, soluble and insoluble fractions were analyzed by SDS-PAGE (Figure 4). The predicted protein sizes of GroEL and TF were 60 and $56 \mathrm{kDa}$, respectively, and the corresponding bands were detected, as shown in Figure 4 . However, GroES (10 kDa) could not be clearly identified. For both $\mathrm{PhaR}_{\mathrm{YB} 4}(18.5 \mathrm{kDa})$ and $\mathrm{PhaC}_{\mathrm{YB} 4}(41.7 \mathrm{kDa})$, the molecular weights were higher than those in a previous study [38], probably due to the N-terminal (His) 6 tag. As shown in Figure 4A, although the GroEL-GroES chaperone did not change the solubilization level of $\mathrm{PhaR}_{\mathrm{YB} 4}$, GroEL-GroES/TF led to a 3.0-fold increase in PhaR $\mathrm{YB}_{\mathrm{YB}}$ solubility (PhaR ${ }_{Y B 4}$ alone, 1.17; +pG-pKJE8, 1.04; +pG-Tf2, 3.62). With regard to the other subunit of $\mathrm{PhaC}_{\mathrm{YB} 4}$, most of the $\mathrm{PhaC}_{\mathrm{YB} 4}$ was found in the insoluble fraction (Figure 4B), indicating that $\mathrm{PhaC}_{\mathrm{YB} 4}$ aggregated easily. Similar to the result for $\mathrm{PhaR}_{\mathrm{YB} 4}$, coexpression of the GroEL-GroES chaperones led to no change in $\mathrm{PhaC}_{Y \mathrm{Y} 4}$ solubility, but that of the GroELGroES/TF chaperones led to an 8.5-fold increase in $\mathrm{PhaC}_{\mathrm{YB} 4}$ solubility ( $\mathrm{PhaC}_{\mathrm{YB} 4}$ alone, 0.28 ; + pG-pKJE8, 0.39; +pG-Tf2, 2.37). These results indicated that not the GroEL-GroES but the GroEL-GroES/TF chaperones support the folding of both $\mathrm{PhaR}_{\mathrm{YB} 4}$ and $\mathrm{PhaC}_{\mathrm{YB} 4}$. When the same experiments were performed with different concentrations of tetracycline (inducer of pG-Tf2), ranging from 0 to $10 \mu \mathrm{g} / \mathrm{L}$, the bands of GroEL and TF were clearly detected with increasing tetracycline concentration (Figure S2).
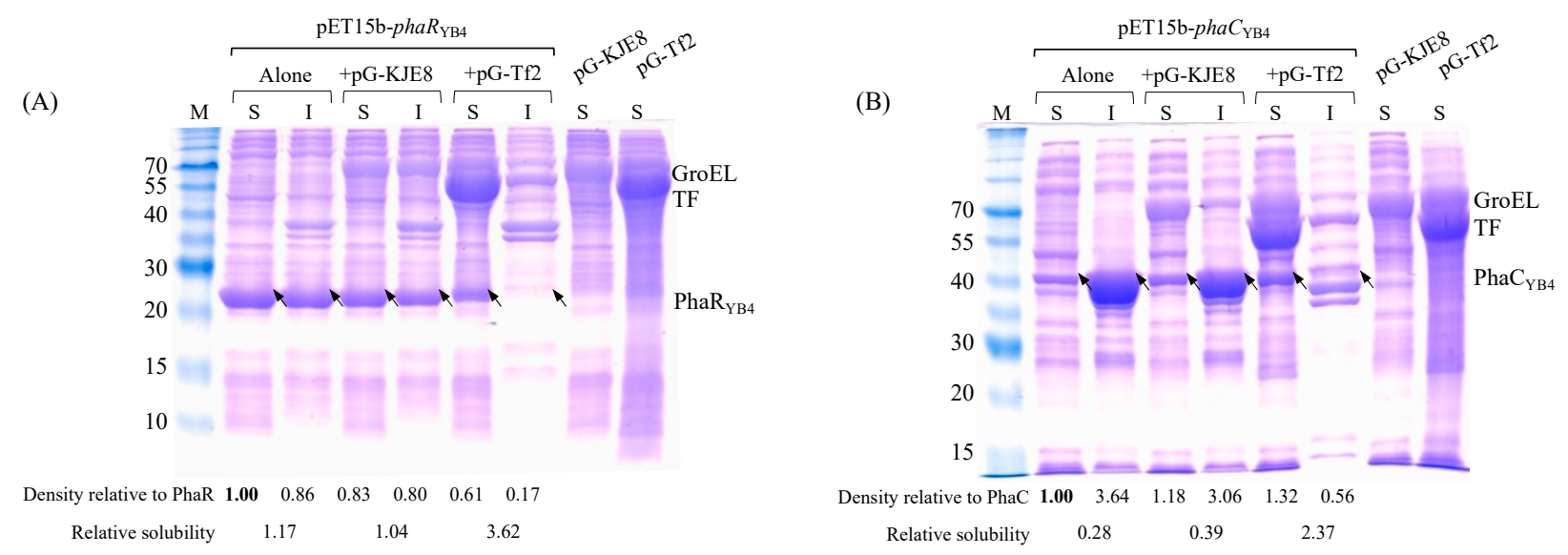

Figure 4. Effect of the chaperone plasmids pG-KJE8 and pG-Tf2 on the solubilization of PhaR YB4 $_{4}$ and $\mathrm{PhaC}_{\mathrm{YB} 4}$. The levels of solubilized $\mathrm{PhaR}_{\mathrm{YB} 4}$ and $\mathrm{PhaC}_{\mathrm{YB} 4}$ were evaluated by SDS-PAGE. (A) $E$.

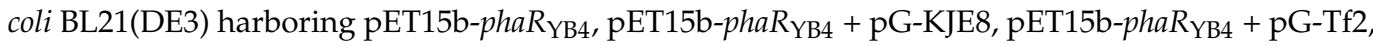

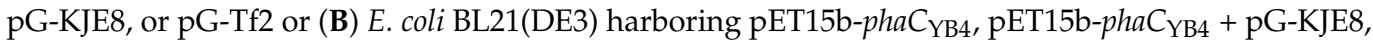


pET15b-pha $\mathrm{C}_{\mathrm{YB} 4}+$ pG-Tf2, pG-KJE8, or pG-Tf2 was cultivated. For strains harboring the chaperone plasmids, $10 \mu \mathrm{g} / \mathrm{L}$ tetracycline (Tc) was added to induce the expression of the chaperones. After sonication of each cell sample, soluble (S) and insoluble (I) fractions were analyzed by SDS-PAGE. The arrows indicate the bands corresponding to $\mathrm{PhaR}_{Y B 4}$ and $\mathrm{PhaC}_{\mathrm{YB} 4}$. The relative densities of the bands were calculated using ImageJ software. The density relative to the band of PhaR $\mathrm{YB}_{4}$ or $\mathrm{PhaC}_{\mathrm{YB} 4}$ is the ratio of the density of each band to that of the band for the soluble fraction of PhaR $\mathrm{YB}_{4}$ or $\mathrm{PhaC}_{\mathrm{YB} 4}$ alone (bold). The relative solubilities are the ratios of the $\mathrm{S}$ to I fractions within each sample.

\section{Discussion}

In this study, we investigated the relationship between the expression level of PHA synthase and $3 \mathrm{HBO}$ generation for the development of an efficient $3 \mathrm{HBO}$ production system. To enhance the expression level of PHA synthase ( $\left.\mathrm{PhaRC}_{\mathrm{YB} 4}\right)$, the major chaperone molecules of E. coli, namely, GroEL-GroES and TF, were coexpressed with related enzymes for $3 \mathrm{HBO}$ synthesis. In the case of the first cultivation of the E. coli BW25113 strain, chaperon expression resulted in higher PHA synthase activity (3.0-fold) and higher $3 \mathrm{HBO}$ production (1.9-fold) (Figure 5, left side). In addition, the time course data of the cultivation showed higher $3 \mathrm{HBO}$ production in both the growth phase and later phase of cultivation (Figure 3), indicating a higher frequency of chain transfer reactions and alcoholysis reactions by the increase in the number of PHA synthase $\left(\mathrm{PhaRC}_{\mathrm{YB} 4}\right)$. It was also revealed that the increased amount of PHA synthase led to a greater number of oligomer chains but did not affect the range of the polymerization degree of the oligomers. The generated $3 \mathrm{HBOs}$ represented an adductive form with ethanol at the carboxyl terminus (Figure 1) because endogenous ethanol functioned as a substrate for chain transfer reaction and alcoholysis reaction.

To remove the effect of ethanol on $3 \mathrm{HBO}$ production and evaluate the effect of the expression level of PHA synthase itself, subsequent cultivation was performed using the non-ethanol-producing strain (BW25113 $\triangle a d h E$ ) as a host strain. As is the case with the wild-type strain, the expression levels of PHA synthase and $3 \mathrm{HBO}$ production were both increased (2.8- and 2.0-fold) by chaperone expression (Figure 5, right side). Chemical structure analysis (ESI-TOFM-MS) of $3 \mathrm{HBOs}$ from the $\triangle a d h E$ strain revealed major amounts of the non-end-capped form of $3 \mathrm{HBOs}$, and minor amounts of the ethanol end-capped form of $3 \mathrm{HBO}$ which was derived from the trace level of ethanol produced by the $\triangle a d h E$ strain (data not shown). To exclude the possibility that the slight difference in ethanol level affected the $3 \mathrm{HBO}$ amount, additional cultivation using $\triangle a d h E$ strains was performed with an equal amount of exogenous ethanol $(0.5,1,3,5$ and $10 \mathrm{~g} / \mathrm{L})$. As a result of cultivation (Table S1), 3HBO production was consistently higher (1.1-4.3-fold) under the chaperone expression conditions, indicating that not the ethanol level but the increase in PHA synthase itself enhanced 3HBO generation. Compared to the ethanol-producing strain (WT strain), the amount of $3 \mathrm{HBOs}$ was greatly reduced, by approximately $1 / 5$, in the non-ethanolproducing strain ( $\triangle a d h E$ strain) (Figure 5), suggesting that the chain transfer reaction and alcoholysis reaction for ethanol were major factors involved in the production of $3 \mathrm{HBOs}$. It was previously reported that $3 \mathrm{HBO}$ production was increased up to 24-fold by the addition of alcohol (DEG) [17]. Thus, an efficient $3 \mathrm{HBO}$ production system should be constructed by considering not only the amount of PHA synthase but also the alcohol type and concentration. 


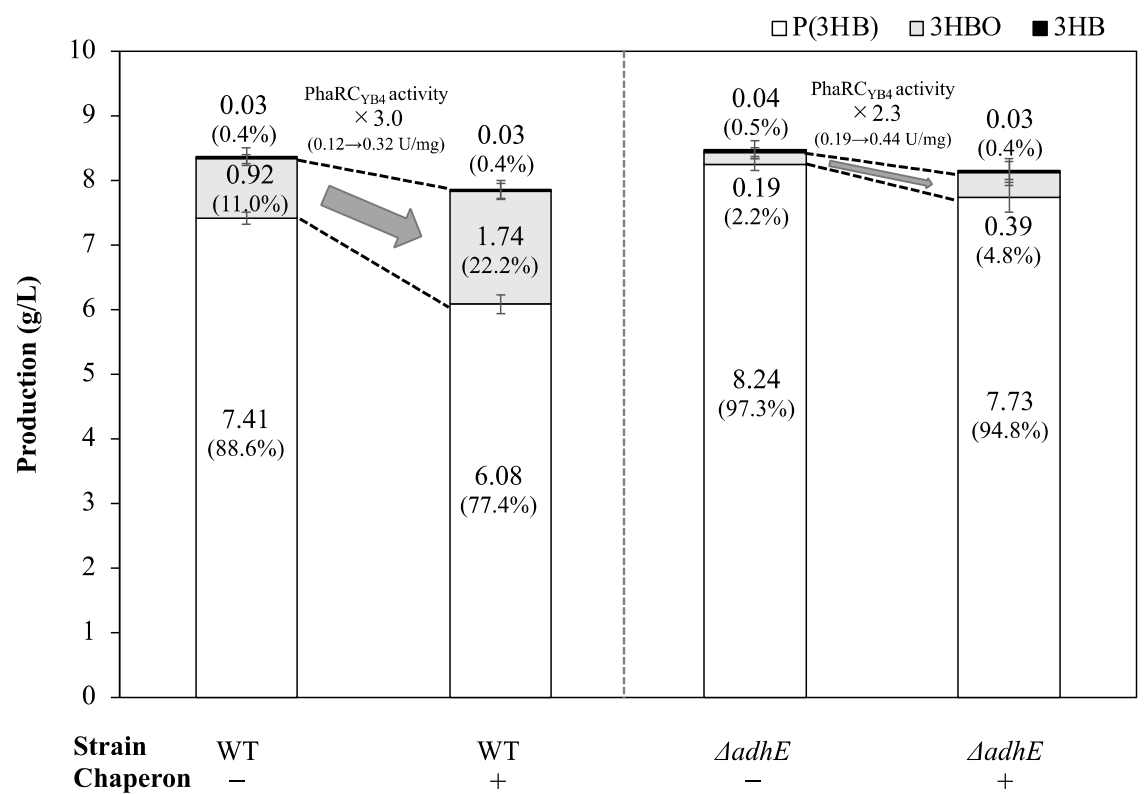

Figure 5. Production profile of $3 \mathrm{HB}$ compounds $(\mathrm{P}(3 \mathrm{HB}), 3 \mathrm{HBO}$, and $3 \mathrm{HB})$ and the distributional change caused by chaperone (GroEL-GroES/TF) expression. The data were derived from Tables 2 and 3.

The association of two types of chaperones (GroEL-GroES and TF) and the expression level of PHA synthases (PhaR $\mathrm{PB}_{4}$ and $\mathrm{PhaC}_{\mathrm{YB} 4}$ ) were supported by data from the pET system-based assay (Figure 4). Previously, it was reported that the GroEL-GroES system acts mainly on 20-50 kDa proteins because of the steric limitation of its cylindrical cavity $[33,39]$. The sizes of the $\mathrm{PhaR}_{\mathrm{YB} 4}$ and $\mathrm{PhaC}_{\mathrm{YB} 4}$ proteins were 18.5 and $41.7 \mathrm{kDa}$, respectively which were within $<50 \mathrm{kDa}$; however, overexpression of GroEL-GroES did not increase the expression level and solubility of PhaR $\mathrm{RB}_{\mathrm{Y} 4}$ and $\mathrm{PhaC}_{\mathrm{YB} 4}$. By comparison, coexpression of the two chaperone systems GroEL-GroES and TF increased the solubility of PhaR $\mathrm{YB}_{\mathrm{Y} 4}$ and $\mathrm{PhaC}_{\mathrm{YB} 4}$ 3.0- and 8.5-fold, respectively, suggesting that TF was the key chaperone that assists in the folding of active $\mathrm{PhaR}_{\mathrm{YB} 4}$ and $\mathrm{PhaC}_{\mathrm{YB} 4}$. Similarly, the effect of chaperones on the expression of a class I PHA synthase from R. eutropha H16 (PhaC $\left.\mathrm{Re}_{\mathrm{Re}}\right)$ was confirmed in a previous study [29]. Comparison of the soluble and insoluble fractions of $\mathrm{PhaC}_{\mathrm{Re}}$ showed that coexpression of two chaperone systems (GroEL-GroES and TF) enhanced the solubilization of $\mathrm{PhaC}_{\mathrm{Re}}$ compared with that of one chaperone system (GroEL-GroES). The same tendency has been observed in other studies on reconstituted cell-free translation systems of E. coli proteins [39,40]. In the cell-free system, it was observed that TF had only a modest effect on the reduction in protein aggregation by itself but could prevent the aggregation of recalcitrant $E$. coli proteins by cooperating with other chaperone systems, including GroEL-GroES [39]. Therefore, it could be considered that the increased solubilization (expression level) of $\mathrm{PhaR}_{\mathrm{YB} 4}$ and $\mathrm{PhaC}_{\mathrm{YB} 4}$ was caused by overexpression of two chaperone systems (GroEL-GroES and TF). Additional cultivation of E. coli BW25113/pGEM-phaRC $C_{Y B} A B+$ pG-KJE8 (GroEL-GroES expressing-strain) also supported this hypothesis since $3 \mathrm{HBO}$ productivity and $\mathrm{PHA}$ synthase activity were not changed from those of the chaperone nonexpressing strain (3HBO production: Control, $0.92 \pm 0.05 \mathrm{~g} / \mathrm{L} ;+$ pG-KJE8, $0.73 \pm 0.09 \mathrm{~g} / \mathrm{L}, \mathrm{PhaRC}_{\text {YB4 }}$ activity: Control, $0.12 \pm 0.06 \mathrm{U} / \mathrm{mg}-$ protein; +pG-KJE8, $0.18 \pm 0.06 \mathrm{U} / \mathrm{mg}$-protein).

\section{Conclusions}

This study demonstrated that the coexpression of chaperone proteins is an effective method for increasing the amount of the active form of $\mathrm{PhaRC}_{\mathrm{YB} 4}$ and the yield of $3 \mathrm{HBOs}$ in E. coli strains. Exploration of more suitable chaperone systems for achieving the best 
expression balance for related enzymes, such as PHA synthase, PhaA, and PhaB, may be a useful strategy for improving the efficiency of $3 \mathrm{HBO}$ production.

Supplementary Materials: The following supporting information can be downloaded at https: / / www.mdpi.com/article/10.3390/microorganisms10020458/s1, Figure S1: Molecular weight distribution of $\mathrm{P}(3 \mathrm{HB})$ extracted from recombinant E. coli BW25113 WT (A) or $\triangle a d h E(\mathrm{~B})$ at $48 \mathrm{~h}$ of cultivation; Figure S2: Effect of the chaperone plasmid pG-Tf2 on the solubilization of PhaR $\mathrm{YB}_{4}$ and PhaC ${ }_{Y B 4}$; Table S1: Effect of coexpression of chaperones on $3 \mathrm{HBO}$ production in recombinant E. coli BW2511 $\triangle a d h E$ with various ethanol concentrations.

Author Contributions: Conceptualization, S.G., Y.M. and A.H.; validation, S.G. and Y.M.; formal analysis, S.G. and Y.M.; investigation, S.G., Y.M. and A.H.; data curation, S.G. and A.H.; writingoriginal draft preparation, S.G. and A.H.; writing-review and editing, S.G., Y.M., S.T., T.T. and A.H.; visualization, S.G. and A.H.; supervision, S.T., T.T. and A.H.; project administration, T.T. and A.H.; funding acquisition, A.H. All authors have read and agreed to the published version of the manuscript.

Funding: This work was supported by Japan Science and Technology Agency (JST)-MIRAI (JPMJMI17EC to A.H.).

Institutional Review Board Statement: Not applicable.

Informed Consent Statement: Not applicable.

Data Availability Statement: Not applicable.

Acknowledgments: The authors thank Mariko Yamada for experimental support and the National Bio Resource Project (NBRP) for providing the E. coli BW25113 and E. coli BW25113 $\triangle$ adhE strains.

Conflicts of Interest: The authors declare no conflict of interest.

\section{References}

1. Steinbüchel, A.; Valentin, H.E. Diversity of bacterial polyhydroxyalkanoic acids. FEMS Microbiol. Lett. 1995, 128, 219-228. [CrossRef]

2. Sudesh, K.; Abe, H.; Doi, Y. Synthesis, structure and properties of polyhydroxyalkanoates: Biological polyesters. Prog. Polym. Sci. 2000, 25, 1503-1555. [CrossRef]

3. Chanprateep, S. Current trends in biodegradable polyhydroxyalkanoates. J. Biosci. Bioeng. 2010, 110, 621-632. [CrossRef] [PubMed]

4. Rehm, B.H.A. Biogenesis of microbial polyhydroxyalkanoate granules: A platform technology for the production of tailor-made bioparticles. Curr. Issues Mol. Biol. 2007, 9, 41-62.

5. Tsuge, T.; Hyakutake, M.; Mizuno, K. Class IV polyhydroxyalkanoate (PHA) synthases and PHA-producing Bacillus. Appl. Microbiol. Biotechnol. 2015, 99, 6231-6240. [CrossRef] [PubMed]

6. Nomura, C.T.; Taguchi, S. PHA synthase engineering toward superbiocatalysts for custom-made biopolymers. Appl. Microbiol. Biotechnol. 2007, 73, 969-979. [CrossRef] [PubMed]

7. Zou, H.; Shi, M.; Zhang, T.; Li, L.; Li, L.; Xian, M. Natural and engineered polyhydroxyalkanoate (PHA) synthase: Key enzyme in biopolyester production. Appl. Microbiol. Biotechnol. 2017, 101, 7417-7426. [CrossRef]

8. Zhang, X.; Lin, Y.; Wu, Q.; Wang, Y.; Chen, G.Q. Synthetic biology and genome-editing tools for improving PHA metabolic engineering. Trends Biotechnol. 2020, 38, 689-700. [CrossRef] [PubMed]

9. Sato, S.; Maruyama, H.; Fujiki, T.; Matsumoto, K. Regulation of 3-hydroxyhexanoate composition in PHBH synthesized by recombinant Cupriavidus necator $\mathrm{H} 16$ from plant oil by using butyrate as a co-substrate. J. Biosci. Bioeng. 2015, 120, $246-251$. [CrossRef]

10. Matsusaki, H.; Abe, H.; Doi, Y. Biosynthesis and properties of poly(3-hydroxybutyrate-co-3-hydroxyalkanoates) by recombinant strains of Pseudomonas sp. 61-3. Biomacromolecules 2000, 1, 17-22. [CrossRef]

11. Yamada, M.; Matsumoto, K.; Uramoto, S.; Motohashi, R.; Abe, H.; Taguchi, S. Lactate fraction dependent mechanical properties of semitransparent poly(lactate-co-3-hydroxybutyrate)s produced by control of lactyl-CoA monomer fluxes in recombinant Escherichia coli. J. Biotechnol. 2011, 154, 255-260. [CrossRef] [PubMed]

12. Hiroe, A.; Ishii, N.; Ishii, D.; Kabe, T.; Abe, H.; Iwata, T.; Tsuge, T. Uniformity of monomer composition and material properties of medium-chain-length polyhydroxyalkanoates biosynthesized from pure and crude fatty acids. ACS Sustain. Chem. Eng. 2016, 4, 6905-6911. [CrossRef]

13. Utsunomia, C.; Matsumoto, K.; Taguchi, S. Microbial secretion of D-lactate-based oligomers. ACS Sustain. Chem. Eng. 2017, 5, 2360-2367. [CrossRef] 
14. Utsunomia, C.; Matsumoto, K.; Date, S.; Hori, C.; Taguchi, S. Microbial secretion of lactate-enriched oligomers for efficient conversion into lactide: A biological shortcut to polylactide. J. Biosci. Bioeng. 2017, 124, 204-208. [CrossRef]

15. Utsunomia, C.; Hori, C.; Matsumoto, K.; Taguchi, S. Investigation of the Escherichia coli membrane transporters involved in the secretion of D-lactate-based oligomers by loss-of-function screening. J. Biosci. Bioeng. 2017, 124, 635-640. [CrossRef] [PubMed]

16. Miyahara, Y.; Hiroe, A.; Tsuge, T.; Taguchi, S. Microbial secretion platform for 3-hydroxybutyrate oligomer and its end-capped forms using chain transfer reaction-mediated polyhydroxyalkanoate synthases. Biotechnol. J. 2019, 14, e1900201. [CrossRef] [PubMed]

17. Hiroe, A.; Sakurai, T.; Mizuno, S.; Miyahara, Y.; Goto, S.; Yamada, M.; Tsuge, T.; Taguchi, S. Microbial oversecretion of (R)-3hydroxybutyrate oligomer with diethylene glycol terminal as a macromonomer for polyurethane synthesis. Int. J. Biol. Macromol. 2021, 167, 1290-1296. [CrossRef]

18. Nduko, J.M.; Taguchi, S. Microbial production of biodegradable lactate-based polymers and oligomeric building blocks from renewable and waste resources. Front. Bioeng. Biotechnol. 2021, 8, 618077. [CrossRef] [PubMed]

19. Kato, N.; Konishi, H.; Shimao, M.; Sakazawa, C. Production of 3-hydroxybutyric acid trimer by Bacillus megaterium B-124. J. Ferment. Bioeng. 1992, 73, 246-247. [CrossRef]

20. Schulz, S.; Toft, S. Identification of a sex pheromone from a spider. Science 1993, 260, 1635-1637. [CrossRef]

21. Ogita, N.; Hashidoko, Y.; Limin, S.H.; Tahara, S. Linear 3-hydroxybutyrate tetramer (HB4) produced by Sphingomonas sp. is characterized as a growth promoting factor for some rhizomicrofloral composers. Biosci. Biotechnol. Biochem. 2006, 70, 2325-2329. [CrossRef] [PubMed]

22. Koskimäki, J.J.; Kajula, M.; Hokkanen, J.; Ihantola, E.L.; Kim, J.H.; Hautajärvi, H.; Hankala, E.; Suokas, M.; Pohjanen, J.; Podolich, O.; et al. Methyl-esterified 3-hydroxybutyrate oligomers protect bacteria from hydroxyl radicals. Nat. Chem. Biol. 2016, 12, 332-338. [CrossRef] [PubMed]

23. Ma, L.; Zhang, Z.; Li, J.; Yang, X.; Fei, B.; Leung, P.H.M.; Tao, X. A new antimicrobial agent: Poly(3-hydroxybutyric acid) oligomer. Macromol. Biosci. 2019, 19, 1970014. [CrossRef]

24. Utsunomia, C.; Saito, T.; Matsumoto, K.; Hori, C.; Isono, T.; Satoh, T.; Taguchi, S. Synthesis of lactate (LA)-based poly(esterurethane) using hydroxyl-terminated LA-based oligomers from a microbial secretion system. J. Polym. Res. 2017, $24,167$. [CrossRef]

25. Hyakutake, M.; Tomizawa, S.; Mizuno, K.; Abe, H.; Tsuge, T. Alcoholytic cleavage of polyhydroxyalkanoate chains by Class IV synthases induced by endogenous and exogenous ethanol. Appl. Environ. Microbiol. 2014, 80, 1421-1429. [CrossRef] [PubMed]

26. Hyakutake, M.; Tomizawa, S.; Mizuno, K.; Hisano, T.; Abe, H.; Tsuge, T. A common active site of polyhydroxyalkanoate synthase from Bacillus cereus YB-4 is involved in polymerization and alcoholysis reactions. Appl. Microbiol. Biotechnol. 2015, 99, 4701-4711. [CrossRef]

27. Tsuge, T. Fundamental factors determining the molecular weight of polyhydroxyalkanoate during biosynthesis. Polym. J. 2016, 48, 1051-1057. [CrossRef]

28. Hiroe, A.; Ushimaru, K.; Tsuge, T. Characterization of polyhydroxyalkanoate (PHA) synthase derived from Delftia acidovorans DS-17 and the influence of PHA production in Escherichia coli. J. Biosci. Bioeng. 2013, 115, 633-638. [CrossRef]

29. Thomson, N.M.; Saika, A.; Ushimaru, K.; Sangiambut, S.; Tsuge, T.; Summers, D.K.; Sivaniah, E. Efficient production of active polyhydroxyalkanoate synthase in Escherichia coli by coexpression of molecular chaperones. Appl. Environ. Microbiol. 2013, 79, 1948-1955. [CrossRef]

30. Hoffmann, A.; Bukau, B.; Kramer, G. Structure and function of the molecular chaperone Trigger Factor. Biochim. Biophys. Acta 2010, 1803, 650-661. [CrossRef] [PubMed]

31. Hartl, F.U.; Bracher, A.; Hayer-Hartl, M. Molecular chaperones in protein folding and proteostasis. Nature 2011, 475, 324-332. [CrossRef]

32. Thomas, J.G.; Ayling, A.; Baneyx, F. Molecular chaperones, folding catalysts, and the recovery of active recombinant proteins from E. coli. Appl. Biochem. Biotechnol. 1997, 66, 197-238. [CrossRef] [PubMed]

33. Kerner, M.J.; Naylor, D.J.; Ishihama, Y.; Maier, T.; Chang, H.C.; Stines, A.P.; Georgopoulos, C.; Frishman, D.; Hayer-Hartl, M.; Mann, M.; et al. Proteome-wide analysis of chaperonin-dependent protein folding in Escherichia coli. Cell 2005, 122, 209-220. [CrossRef] [PubMed]

34. Tomizawa, S.; Hyakutake, M.; Saito, Y.; Agus, J.; Mizuno, K.; Abe, H.; Tsuge, T. Molecular weight change of polyhydroxyalkanoate (PHA) caused by the PhaC subunit of PHA synthase from Bacillus cereus YB-4 in recombinant Escherichia coli. Biomacromolecules 2011, 12, 2660-2666. [CrossRef] [PubMed]

35. Baba, T.; Ara, T.; Hasegawa, M.; Takai, Y.; Okumura, Y.; Baba, M.; Datsenko, K.A.; Tomita, M.; Wanner, B.L.; Mori, H. Construction of Escherichia coli K-12 in-frame, single-gene knockout mutants: The Keio collection. Mol. Syst. Biol. 2006, 2, 2006.0008. [CrossRef]

36. Kato, M.; Bao, H.J.; Kang, C.K.; Fukui, T.; Doi, Y. Production of a novel copolyester of 3-hydroxybutyric acid and mediumchain-length 3-hydroxyalkanoic acids by Pseudomonas sp. 61-3 from sugars. Appl. Microbiol. Biotechnol. 1996, 45, 363-370. [CrossRef]

37. Fukui, T.; Yoshimoto, A.; Matsumoto, M.; Hosokawa, S.; Saito, T.; Nishikawa, H.; Tomita, K. Enzymatic synthesis of poly- $\beta$ hydroxybutyrate in Zoogloea ramigera. Arch. Microbiol. 1976, 110, 149-156. [CrossRef]

38. Kihara, T.; Hiroe, A.; Ishii-Hyakutake, M.; Mizuno, K.; Tsuge, T. Bacillus cereus-type polyhydroxyalkanoate biosynthetic gene cluster contains R-specific enoyl-CoA hydratase gene. Biosci. Biotechnol. Biochem. 2017, 81, 1627-1635. [CrossRef] 
39. Niwa, T.; Kanamori, T.; Ueda, T.; Taguchi, H. Global analysis of chaperone effects using a reconstituted cell-free translation system. Proc. Natl. Acad. Sci. USA 2012, 109, 8937-8942. [CrossRef] [PubMed]

40. Niwa, T.; Ying, B.W.; Saito, K.; Jin, W.; Takada, S.; Ueda, T.; Taguchi, H. Bimodal protein solubility distribution revealed by an aggregation analysis of the entire ensemble of Escherichia coli proteins. Proc. Natl. Acad. Sci. USA 2009, 106, 4201-4206. [CrossRef] 